\title{
Colposcopy: An Evidence-Based Update
}

\author{
Lee T. Dresang, MD
}

Colposcopy is a diagnostic procedure, most commonly used in the diagnosis of cervical intraepithelial neoplasia and lower genital tract carcinoma. In this article, evidence-based management strategies are updated with discussion of the 2001 American Society for Colposcopy and Cervical Pathology Consensus Guidelines. Practice management issues include methods to improve cervical cancer screening rates, coding and billing, and telemedicine. Textbooks, CD-ROMs, and courses are listed for new learners and experienced providers who want to update and sharpen their skills. (J Am Board Fam Pract 2005;18: 383-92.)

Worldwide, cervical cancer is the second leading cause of cancer death among women. ${ }^{1}$ Introducing cervical screening programs to areas without them results in a $60 \%$ to $90 \%$ reduction in cervical cancer rates within 3 years. ${ }^{2}$ In the United States, Papanicolaou (Pap) screening has been used since the 1940s and colposcopy since the 1970 s. $^{3}$ Cervical cancer remains the 10th leading cause of cancer death among US women with approximately 13,000 new cases and 4,100 deaths in 2002. ${ }^{2}$ This evidence-based update on colposcopy covers indications, technique, management recommendations, practice management issues, and available resources.

\section{Indications for Colposcopy}

Recommendations for when to perform colposcopy have changed with the 2001 American Society for Colposcopy and Cervical Pathology (ASCCP) Consensus Guidelines. Table 1 lists colposcopy indications, the most common being an abnormal Pap. Figure 1 illustrates recommendations for the management of abnormal cytology according to 2001 ASCCP Consensus Guidelines. ${ }^{4}$

\section{Atypical Squamous Cells}

The 2001 Bethesda system subdivides atypical squamous cells (ASC) into atypical squamous cells

Submitted, revised, 1 April 2005.

From the University of Wisconsin Medical School, Department of Family Medicine, St. Luke's Family Practice Residency, Milwaukee, Wisconsin.

Conflict of interest: none declared.

Corresponding author: Lee T. Dresang, MD, Associate Professor, 1230 W. Grant Street, Milwaukee, WI 53215 (e-mail: ldresang@fammed.wisc.edu). of undetermined significance (ASC-US) and ASC"cannot exclude high grade squamous intraepithelial lesion" (ASC-H)..$^{5}$ ASC-H is an indication for colposcopy. For ASC-US, providers may repeat cervical cytology at 4 to 6 and 12 months, perform human papillomavirus (HPV) DNA testing, or proceed to immediate colposcopy. Colposcopy is recommended if the repeat cytology is ASC-US or greater, or HPV testing is positive for high risk types $(16,18,31,33,35,39,45,51,52,56,59$, and $68)^{6}$

2001 ASCCP Consensus Guidelines recommend HPV testing for management of ASC-US. ${ }^{4}$ A 2002 cost-effectiveness study found reflex HPV testing for high risk DNA types for all ASC-US Pap results using liquid-based cytology "provides the same or greater life expectancy benefits and is more cost-effective than other management strategies."7

\section{Low Grade Squamous Intraepithelial Lesion and High Grade Squamous Intraepithelial Lesion Terminology}

Pap results were first classified as low grade squamous intraepithelial lesion (LSIL) and high grade squamous intraepithelial lesion (HSIL) through the 1988 Bethesda system; the LSIL/HSIL terminology remains unchanged in the 2001 Bethesda system. ${ }^{5}$ LSIL refers to cervical intraepithelial neoplasia (CIN)-1/mild disease. HSIL incorporates the previous categories of $\mathrm{CIN}-2 /$ moderate dysplasia, CIN-3/severe dysplasia and carcinoma in situ. The new LSIL/HSIL nomenclature is "a more reliable, reproducible way to classify lesions with malignant 
Table 1. Indications for Colposcopy

\begin{tabular}{l} 
Abnormal Papanicolaou \\
ASC-US* \\
ASC-US twice \\
ASC-US with high risk HPV types \\
ASC-H \\
LSIL \\
HSIL \\
AGC \\
Cervical lesion \\
Condyloma accuminata \\
Polyp \\
Vaginal lesion \\
Warts \\
Ulcers \\
Vulvar lesion \\
Genital warts \\
Ulcer \\
Mole concerning for melanoma \\
Follow-up LEEP, cryotherapy, cone biopsy \\
Intrauterine diethylstilbestrol exposure \\
Sexual partner with genital warts or condyloma accuminata \\
Sexual abuse \\
\hline
\end{tabular}

* ASC-US, atypical squamous cells of undetermined significance; HPV, human papillomavirus; LSIL, low grade squamous intraepithelial lesion; HSIL, high grade SIL; AGC, atypical glandular cells; LEEP, loop electrosurgical excision procedure.

potential." 8 The SIL, CIN, and dysplasia terminology can be used for cytology (Papanicolaou) and histology (biopsy) results. With the SIL terminology of the Bethesda system, "CIN or dysplasia terminology can be used, either as a substitute for SIL or as an additional descriptor." 52001 ASCCP Consensus Guidelines principally use SIL terminology for cytology results and CIN terminology for histology results. ${ }^{4,9}$

\section{Low Grade Squamous Intraepithelial Lesion}

Patients with LSIL cytology should be evaluated with a colposcopy. HPV testing is not recommended for LSIL cytology because $83 \%$ of patients with LSIL are positive for high risk HPV types. ${ }^{10}$ Repeat cytology is not recommended for LSIL.

\section{High Grade Squamous Intraepithelial Lesion}

HSIL cytology can be evaluated with colposcopy or treated directly with a "see and treat" procedure such as loop electrosurgical excision procedure (LEEP). Because a "see and treat" approach may lead to over-treatment, it is best reserved for patients at risk for loss to follow-up. ${ }^{4}$

Cervical treatment options include ablation procedures (cryotherapy) and excisional procedures (LEEP, laser, and cold-knife conization). LEEP can be subdivided into large loop excision of the transformation zone (LLETZ) and LEEP conization, involving a deeper endocervical sample through the use of a second loop. Cervical conization procedures (LEEP, laser, and cold-knife) can be diagnostic and/or therapeutic. The LEEP used in a "see and treat" approach to HSIL is usually a LLETZ, which is both diagnostic and therapeutic.

\section{Atypical Glandular Cells}

The 2001 Bethesda system replaced the term atypical glandular cells of uncertain significance (AGUS) with the term atypical glandular cells (AGC), with the subclassifications: not otherwise specified (NOS), favor neoplasia, endocervical adenocarcinoma in situ (AIS). The risk of premalignant or malignant disease is $9 \%$ to $41 \%$ for AGC NOS Papanicolaou results vs $96 \%$ for AGC favor neoplasia. ${ }^{11}$ All AGC Pap results should be evaluated with a colposcopy and endocervical sampling, with the exception that women with atypical endometrial cells should be initially evaluated with endometrial sampling. In the absence of atypical endometrial cells, endometrial sampling is indicated for AGC results if the patient is over age 35 or bleeding irregularly. ${ }^{4}$

\section{Sexual Abuse}

Colposcopy is often used for documenting sexual abuse. Some colposcopes allow photography. The hymen is carefully examined for signs of trauma. The green filter can bring out avascular areas caused by scarring. ${ }^{12,13}$

\section{Cervical Polyp}

"Polyps can be neoplastic, and may be the presenting sign of cervical neoplasia or endometrial cancer. They should be biopsied or removed for histologic evaluation." ${ }^{14}$ If endocervical polyp origin is not evident on colposcopy, a transvaginal pelvic ultrasound should be performed: some polyps protruding from the cervix may originate high in the uterus.

\section{Suspicious Lesions of Genital Track}

Suspicious lesions (including warts, plaques, and ulcers) of the genital track (cervix, vagina, and vulva) should be investigated with colposcopy re- 


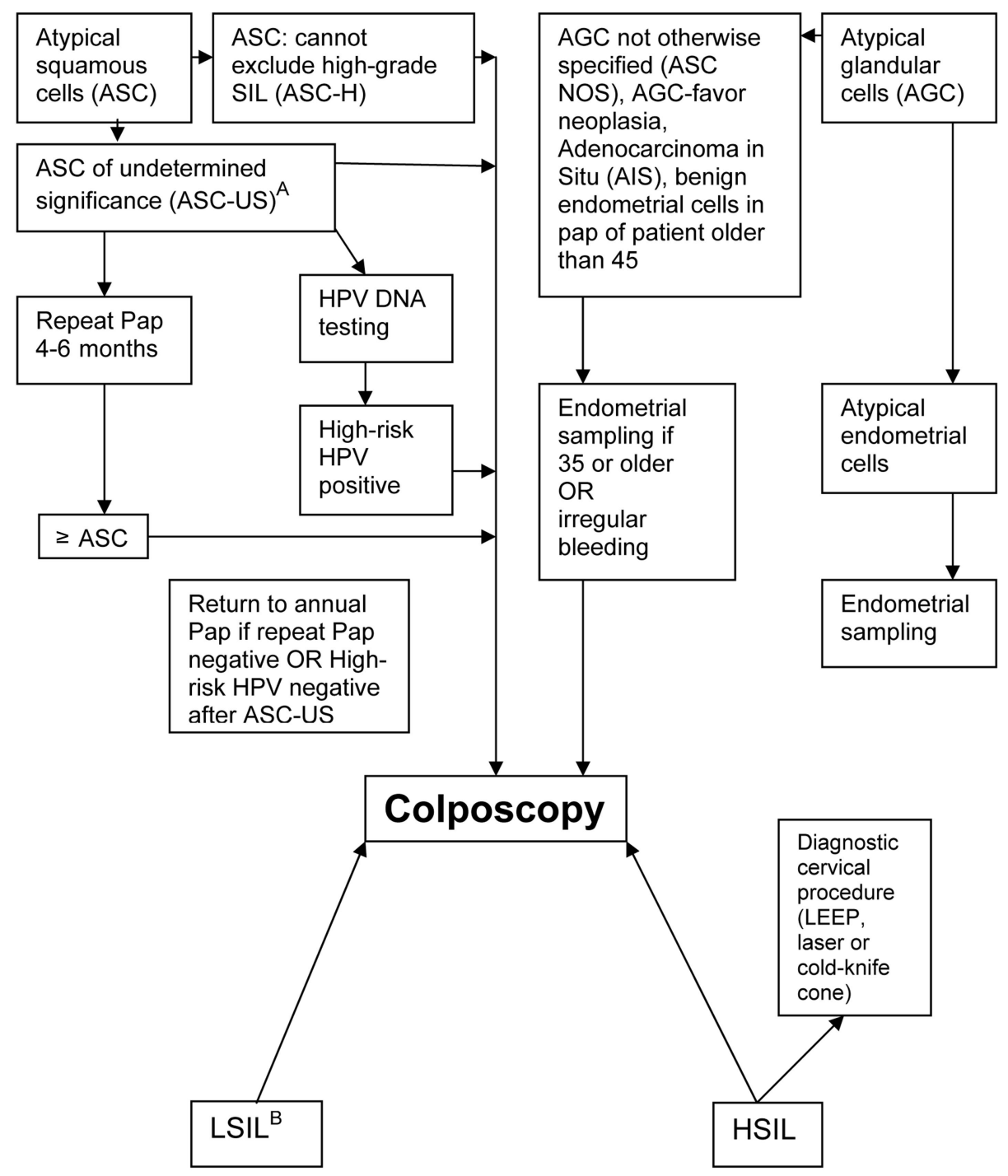

A ASC-US in a post menopausal woman may be followed by hormonal treatment and repeat Pap

LSIL in adolescents may be followed by a Pap and HPV testing in 12 months; LGSIL in postmenopausal women may be followed by hormonal treatment and repeat Pap; A persistent abnormal Pap warrants colposcopy

Figure 1. Recommendations for Management of Women with Cytological Abnormalities According to 2001 ASCCP Consensus Guidelines.

gardless of Pap results. It is possible to have cancer despite a normal Pap. ${ }^{15}$

\section{Technique}

A comprehensive review of anatomy, pathophysiology, and colposcopic technique is beyond the scope of this paper, but can be obtained through the resources listed in Tables 2 and 3. Figure 2 illustrates the appearance of acetowhite changes, punctation, and mosaicism with the application of $3 \%$ to $5 \%$ acetic acid. Evidence supporting the sleeved cytobrush (Figure 3) as an alternative to an endocervical curettage (ECC) and colposcopic technique in pregnancy, adolescence, and menopause are discussed below.

\section{Cytobrush versus Endocervical Curettage}

A study since the 2001 ASCCP Consensus Guidelines showed that a cytobrush with a sleeve (straw) is more sensitive and less painful, with less specimen inadequacy. A cytobrush is rotated 360 degrees briskly 5 times and pulled back into the straw 
Table 2. Colposcopy Books

\begin{tabular}{|c|c|c|c|}
\hline Category & Reference & Description & Price \\
\hline \multirow[t]{3}{*}{ Introductory book } & $\begin{array}{l}\text { Sellers JW, Sankaranarayanan R. Colposcopy } \\
\text { and treatment of cervical intraepithelial } \\
\text { neoplasia, a beginners' manual. Intl. } \\
\text { Agency for Research on Cancer, } 2003 \text {. }\end{array}$ & $\begin{array}{l}144 \text { pages; introductory manual; may help } \\
\text { implementation in developing countries }\end{array}$ & $\$ 20.50$ \\
\hline & $\begin{array}{l}\text { Soutter P, Soutter WP. A practical guide to } \\
\text { colposcopy (Oxford Medical Publications). } \\
\text { Oxford University Press; } 1997 .\end{array}$ & $\begin{array}{l}272 \text { pages; guide for those setting up a } \\
\text { colposcopy clinic; ways of helping to } \\
\text { minimize patient anxiety suggested }\end{array}$ & $\$ 158.82$ \\
\hline & $\begin{array}{l}\text { Luesley D, Shafi M, Jordan J (editors). } \\
\text { Handbook of colposcopy, 1st Ed. } \\
\text { Lippincott, Williams \& Wilkins } \\
\text { Publishers; } 1996 .\end{array}$ & $\begin{array}{l}164 \text { pages; based on course run by the } \\
\text { British Society of Colposcopy and } \\
\text { Cervical Pathology; introduction for } \\
\text { beginners }\end{array}$ & $\$ 67.50$ \\
\hline \multirow[t]{6}{*}{ Atlas and textbook } & $\begin{array}{l}\text { Baggish MS, Baggish M. Colposcopy of the } \\
\text { cervix, vagina, and vulva: a comprehensive } \\
\text { textbook. Mosby, Inc.; } 2003 \text {. }\end{array}$ & $\begin{array}{l}384 \text { pages; textbook and atlas; color photos; } \\
\text { discussion of colposcopy of the cervix, } \\
\text { vagina and vulva followed by case } \\
\text { illustrations }\end{array}$ & $\$ 149.00$ \\
\hline & $\begin{array}{l}\text { Colposcopy: a medical dictionary, } \\
\text { bibliography, and annotated research } \\
\text { guide to internet references. Icon Health } \\
\text { Publications; } 2003 \text {. }\end{array}$ & $\begin{array}{l}152 \text { pages; terms related to colposcopy; } \\
\text { bibliography, internet resources }\end{array}$ & $\$ 34.95$ \\
\hline & $\begin{array}{l}\text { Prendiville W, Ritter J, Tatti S. (Editors). } \\
\text { Colposcopy: management options. WB } \\
\text { Saunders Company; 2003. }\end{array}$ & $\begin{array}{l}160 \text { pages; textbook and atlas; } 120 \text { color } \\
\text { photographs }\end{array}$ & $\$ 79.95$ \\
\hline & $\begin{array}{l}\text { Apgar S. Spitzer M, Brotzman GL, } \\
\text { Ignatavicius DD. Colposcopy: principles } \\
\text { and practice: an integrated textbook and } \\
\text { atlas. 1st ed. WB Saunders Company, } \\
2002 \text {. }\end{array}$ & $\begin{array}{l}512 \text { pages; textbook and atlas; color photos; } \\
\text { highlights correlations between cytology, } \\
\text { colposcopy and histology }\end{array}$ & $\$ 99.00$ \\
\hline & $\begin{array}{l}\text { Burghardt E, Pickel H, Girardi F. Primary } \\
\text { care colposcopy: textbook and atlas, 1st } \\
\text { Ed. Thieme Medical Publishers; } 2002 \text {. }\end{array}$ & $\begin{array}{l}168 \text { pages; textbook and atlas; equipment, } \\
\text { training, exam techniques, normal and } \\
\text { abnormal colposcopic findings, differential } \\
\text { diagnosis and treatment }\end{array}$ & $\$ 61.62$ \\
\hline & $\begin{array}{l}\text { Singer A, Monaghan JM, Chong S. Lower } \\
\text { genital tract precancer: colposcopy, } \\
\text { pathology and treatment, 2nd Ed. } \\
\text { Blackwell Science Inc.; } 2000 .\end{array}$ & $\begin{array}{l}323 \text { pages; textbook and atlas; new section } \\
\text { on AIDS and chapter on pathology }\end{array}$ & $\$ 230.95$ \\
\hline
\end{tabular}

before removing. This technique may prevent contamination of the endocervical sample with ectocervical disease. Specimen inadequacy was 2\% compared with $22 \%$ with an ECC. ${ }^{16}$

\section{Colposcopy in Pregnancy}

ECC is contraindicated during pregnancy. Ectropion (eversion) of the cervix with migration of the transformation zone (eversion of endocervical epithelium) may lead to an increased percentage of satisfactory colposcopies during pregnancy. When the everted columnar cells are exposed to the vaginal environment, they undergo metaplasia. This may increase the frequency of normal acetowhite changes noted. The incidence of CIN is similar in pregnant and non-pregnant women. ${ }^{17}$

The purpose of colposcopy during pregnancy is to detect severe dysplasia or cancer. Unless invasive cancer is identified, treatment is unacceptable. Le- sions that do not appear severe in nature need not be biopsied. Serial cytology and colposcopy should be performed throughout pregnancy with biopsy of worsening lesions or with cytology indicating invasive disease. It is important that patients return for a colposcopy at least 6 weeks after delivery. ${ }^{4}$

\section{Colposcopy in Adolescents}

In general, a diagnostic excisional procedure (LEEP, laser, or cold-knife conization) is recommended for patients with HSIL cytology but a normal or CIN-1 histology. In adolescents, it is acceptable to observe CIN-2 histology with repeat colposcopy every 4 to 6 months for 1 year if the endocervical sample is negative and the patient accepts the risk of occult disease. If the HSIL Pap result persists, a diagnostic excisional procedure is recommended. ${ }^{4}$ 


\begin{tabular}{|c|c|c|c|}
\hline CD-ROM & Content & Ordering Information & Price \\
\hline $\begin{array}{l}\text { Brotzman G, Spitzer, Apgar } \\
\text { B. Colposcopy image } \\
\text { library. National } \\
\text { Procedures Institute; } \\
2003 .\end{array}$ & $\begin{array}{l}\text { Over } 800 \text { colposcopic } \\
\text { images linked to } 31 \text { key } \\
\text { terms; demonstrate over } \\
3000 \text { colposcopic features }\end{array}$ & $\begin{array}{l}\text { American Society for } \\
\text { Colposcopy and Cervical } \\
\text { Pathology, 20 West } \\
\text { Washington Street; Suite } \\
\text { 1, Hagerstown, MD } \\
\text { 21740, 800-787-7227, } \\
\text { http://www.asccp.org/ } \\
\text { bookstore.shtml\# }\end{array}$ & $\begin{array}{l}\text { \$170 ASCCP members; } \\
\$ 190 \text { non-members }\end{array}$ \\
\hline $\begin{array}{l}\text { Spitzer M, Jones H, } \\
\text { Runowicz CD, Waggoner } \\
\text { SE. Advanced colposcopy } \\
\text { American College of } \\
\text { Obstetrics and } \\
\text { Gynecology/American } \\
\text { Society for Colposcopy } \\
\text { and Cervical Colposcopy; } \\
2002 \text {. }\end{array}$ & $\begin{array}{l}\text { Interactive tutorials and } 26 \\
\text { case presentations; } 2001 \\
\text { Bethesda system } \\
\text { terminology }\end{array}$ & $\begin{array}{l}\text { American Society for } \\
\text { Colposcopy and Cervical } \\
\text { Pathology, 20 West } \\
\text { Washington Street; Suite } \\
\text { 1, Hagerstown, MD } \\
\text { 21740, 800-787-7227, } \\
\text { http://www.asccp.org/ } \\
\text { bookstore.shtml\# }\end{array}$ & $\begin{array}{l}\text { \$175 ASCCP members; } \\
\$ 195 \text { non-members }\end{array}$ \\
\hline $\begin{array}{l}\text { American Academy of } \\
\text { Family Physicians. } \\
\text { Colposcopy for the family } \\
\text { physician; } 1998\end{array}$ & $\begin{array}{l}\text { Video and audio clips, } \\
\text { searchable text } \\
\text { documents, interactive } \\
\text { test }\end{array}$ & $\begin{array}{l}\text { American Academy of } \\
\text { Family Physicians } \\
\text { (AAFP), 11400 } \\
\text { Tomahawk Creek } \\
\text { Parkway, Leawood, KS } \\
\text { 66211, 800-944-0000, } \\
\text { http://www.aafp.org/x18319.xml }\end{array}$ & $\begin{array}{l}\$ 110 \text { AAFP members; } \$ 140 \\
\text { non-members }\end{array}$ \\
\hline $\begin{array}{l}\text { Anderson M, Jordan JA, } \\
\text { Morse AR, Sharp F. } \\
\text { Integrated colposcopy: } \\
\text { for colposcopists, } \\
\text { histopathologists and } \\
\text { cytologists. Lippincott, } \\
\text { Williams \& Wilkins } \\
\text { Publishers; 1997. }\end{array}$ & $\begin{array}{l}\text { Module 1: cytology, } \\
\text { colposcopy and histology; } \\
\text { Module 2: } \sim 1000 \text { color } \\
\text { images; Module 3: over } \\
30 \text { cases }\end{array}$ & www.amazon.com & $\$ 325$ \\
\hline
\end{tabular}

\section{Colposcopy after Menopause}

Postmenopausal atrophy can result in abnormal cytology. A postmenopausal woman with an LSIL Pap result may undergo estrogen treatment followed by repeat Pap every 4 to 6 months. Estrogen cream is applied intravaginally each evening for 4 weeks and stopped 1 week before repeat cytology. Postmenopausal patients with LSIL undergoing estrogen treatment may return to annual Pap after 2 normal results. An ASC or more severe abnormality on Pap after estrogen treatment should be evaluated with colposcopy. Recommended management of HSIL cytology is not effected by menopausal status. ${ }^{4}$

Because of hormonal changes, many postmenopausal women will have an unsatisfactory colposcopy. A colposcopy is considered unsatisfactory if the entire transformation zone cannot be visualized and if the distal end of a lesion extending into the endocervical canal cannot be visualized. In postmenopausal women, the former is often true. Estrogen treatment described in the previous paragraph will often cause enough ectropion of the endocervical cells to result in a satisfactory examination. ${ }^{4}$

\section{Follow-Up of Histology or Colposcopy Results} 2001 ASCCP Consensus Guidelines for managing histology are depicted in Figure 4. ${ }^{9}$

\section{Unsatisfactory Examination}

Management of an unsatisfactory colposcopic examination depends on cervical cytology and histology. An unsatisfactory examination following HSIL warrants a diagnostic excisional procedure. In addition, a diagnostic excisional procedure is recommended after an unsatisfactory examination with biopsy proven CIN-1, CIN-2, or CIN-3. If colposcopic histology is normal and cytology is less severe than HSIL, repeating a Pap at 6 and 12 months, HPV testing at 1 year, or a Pap and colposcopy at 1 year are all acceptable. ${ }^{9}$ An unsatisfactory examination in a post-menopausal woman is addressed in the Colposcopy after Menopause section above. 

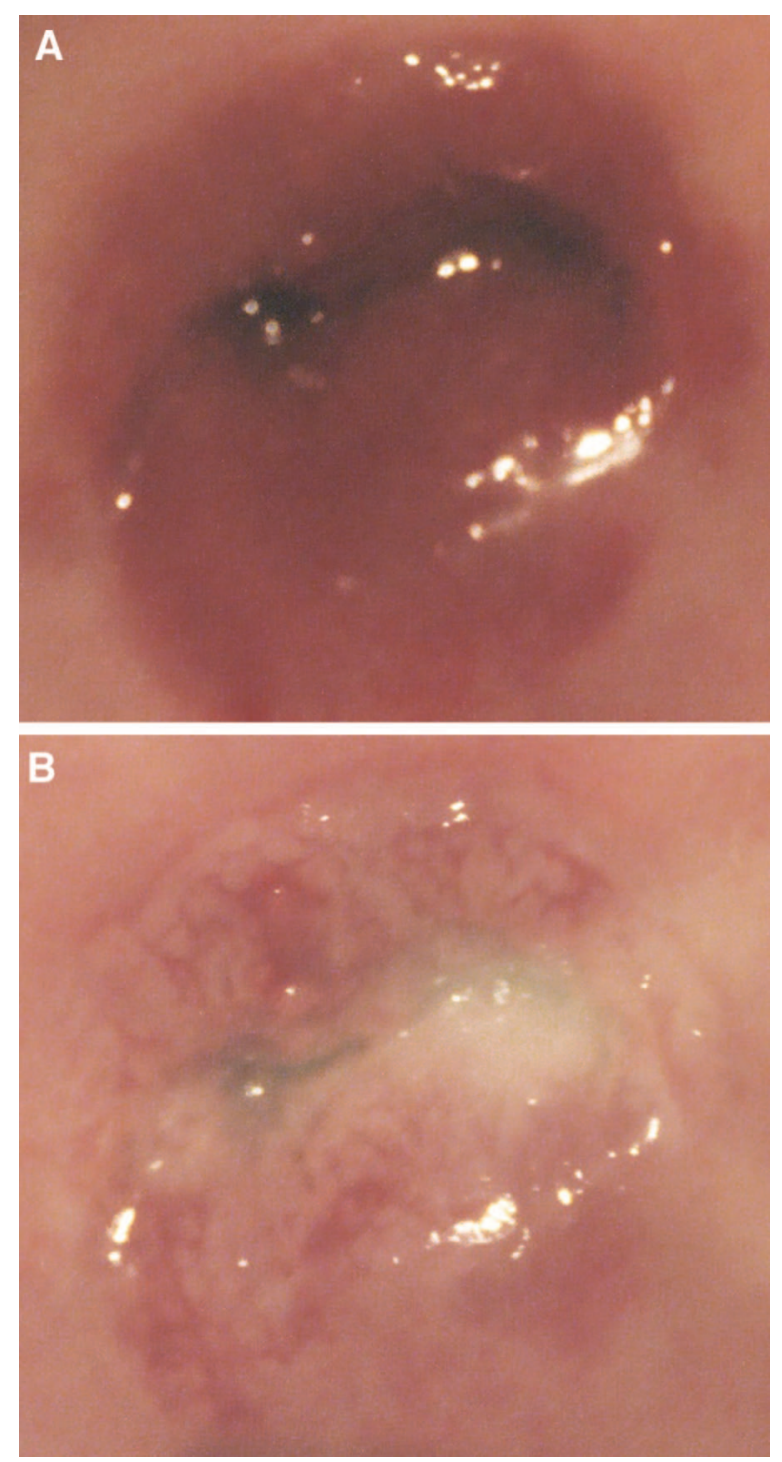

Figure 2. Cervix before and after Application of Acetic Acid.

\section{Normal}

Additional testing is indicated after a normal colposcopy to help avoid missed pathology. A satisfactory colposcopy negative for dysplasia following HSIL, AGC favor neoplasia (FN) or endocervical AIS warrants a diagnostic excisional procedure, preferably a cold-knife cone for AGC FN and AIS. Repeat Pap every 4 to 6 months until 4 consecutive negative results are obtained is the recommended follow-up of a normal, satisfactory colposcopy after AGC NOS cytology. The same examination, following ASC or LSIL cytology, warrants repeating a Pap at 6 and 12 months, HPV testing at 1 year, or a Pap and colposcopy at 1 year. ${ }^{9}$
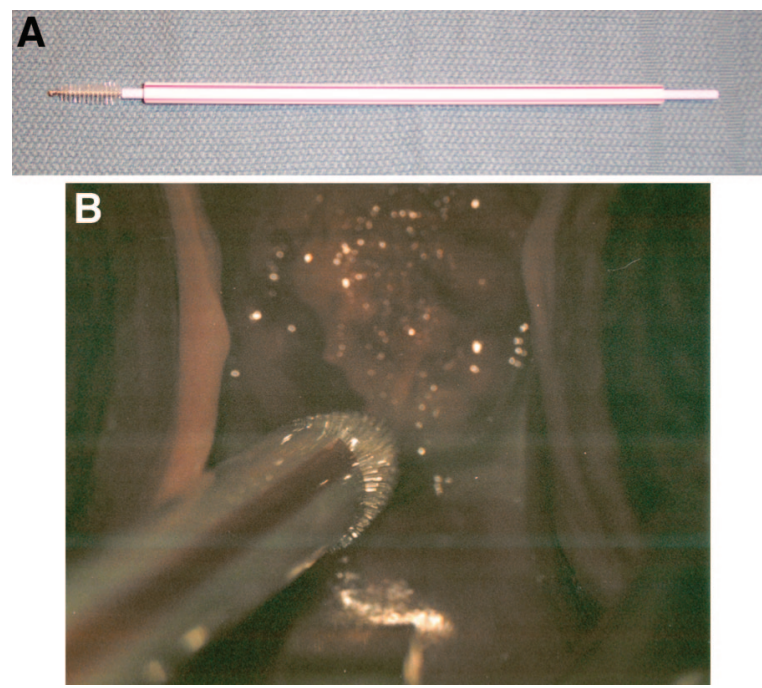

Figure 3. Cytobrush with Sleeve.

\section{CIN-1}

When colposcopy is satisfactory, observation or treatment of biopsy confirmed CIN-1 is acceptable. Acceptable observation options include: (1) repeat Pap at 6 and 12 months, (2) HPV testing at 12 months, and (3) repeat Pap and colposcopy at 12 months. Acceptable treatment modalities include: (1) cryotherapy, (2) laser ablation, and (3) LEEP. Endocervical sampling is recommended before ablation of CIN-1. ${ }^{9}$

\section{CIN-2,3}

Observation with biopsy confirmed CIN-2,3 is unacceptable, except in special circumstances including adolescents with CIN-2 and pregnant patients. When colposcopy is satisfactory and the endocervical sample is negative, excision and ablation are acceptable. With recurrent $\mathrm{CIN}-2,3$, excisional modalities are preferred. In immunosuppressed individuals, such as those with the human immunodeficiency virus, biweekly, topical vaginal 5 -fluorouracil may be used after treatment to reduce the risk of recurrent cervical dysplasia. ${ }^{9}$

\section{Cancer}

A woman with micro or invasive cancer on colposcopic directed biopsy should be referred to an appropriate specialist.

\section{Practice Management}

Colposcopy practice management issues include strategies to increase Pap screenings, follow-up of results, and coding and billing. 


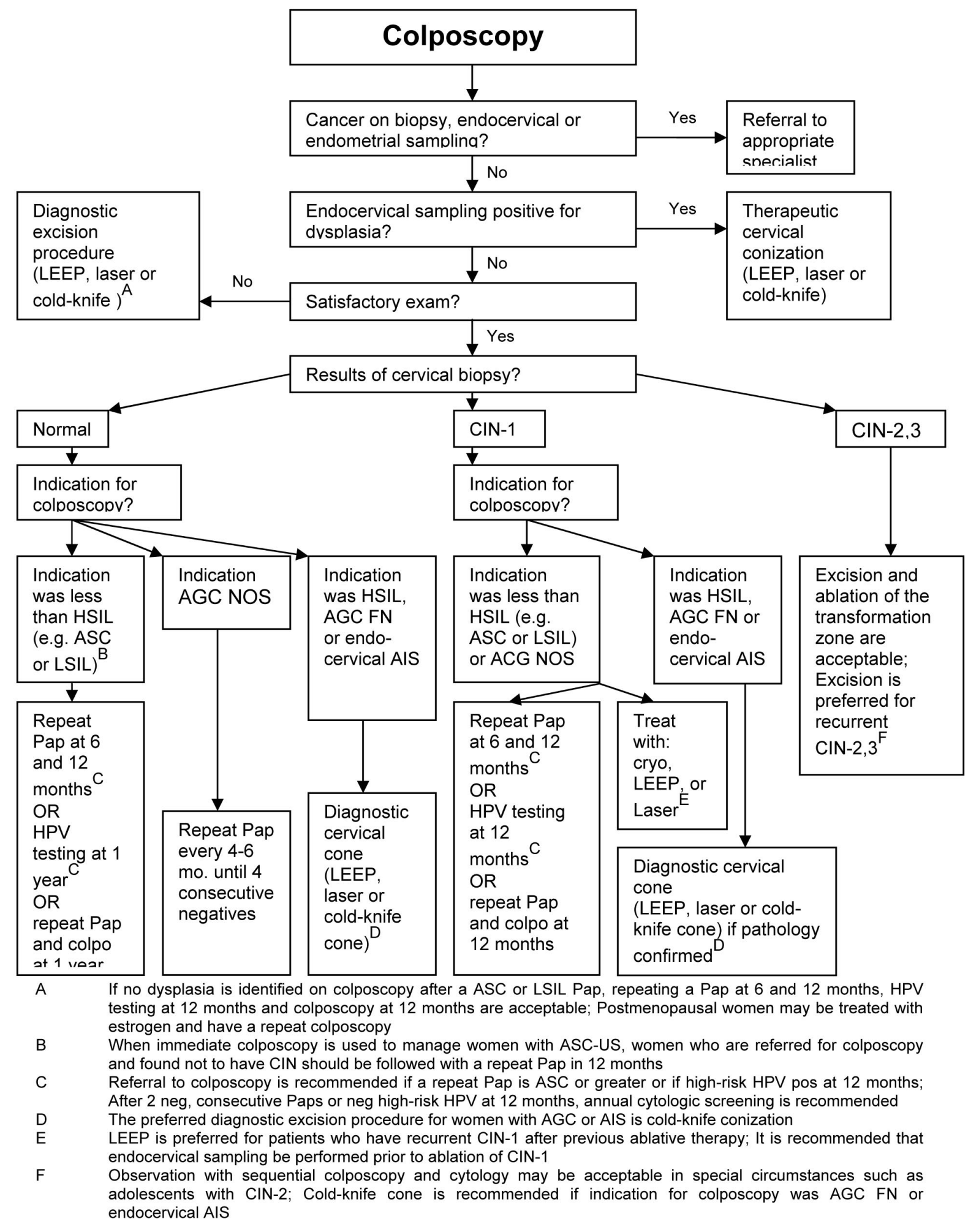

Figure 4. Management of Colposcopic Findings.

\section{Increasing Pap Screenings}

Screening with Pap to know when colposcopy is indicated is as important as providing colposcopy when indicated. Of US women with cervical cancer, $50 \%$ have never had a Pap and another 10\% have not had a Pap in the 5 years before diagno- 
Table 4. Colposcopy ICD-9 Codes $^{24}$

\begin{tabular}{ll}
\hline ICD-9 Code & \multicolumn{1}{c}{ Description } \\
\hline 078.11 & Condyloma accuminata \\
078.19 & Genital warts \\
616.50 & Vulvar ulcer \\
616.8 & Cervical ulcer \\
622.1 & Abnormal Papanicolaou test \\
622.7 & Polyp of cervix \\
624.8 & Vulvar mole no specific diagnosis \\
654.60 & Abnormality of cervix in pregnancy \\
995.53 & Sexual abuse \\
V01.7 & Sexual partner with genital warts or condyloma \\
& accuminata \\
\hline
\end{tabular}

sis. ${ }^{18}$ Evidence supports patient reminders as one way of increasing Pap rates. ${ }^{19}$

\section{Computerized Tracking Systems}

Many health systems are able to track whether registered patients are up to date on their Pap screening and whether they have followed up on any abnormal results. Tracking systems can alert patients to the need for an appointment and can alert providers to patients who may otherwise be lost to follow-up with dangerous consequences.

\section{Telemedicine and Rural Practice}

Telecolposcopy involves a local provider taking colposcopic images (still and/or video) which are transmitted electronically to an expert colposcopist for interpretation and recommendations. The distant reading of the images may be real-time or delayed..$^{20}$ Barriers to telecolposcopy include: "the initial cost of capitalization, reimbursement, and licensing challenges, as well as the threat of malpractice." ${ }^{21}$ In remote rural areas, colposcopy performed by local providers is less costly than telemedicine with expert consultation. ${ }^{22}$ However, colposcopists' and patients' satisfaction with telecolposcopy is high. In one study, over $95 \%$ of women who lived more than 25 miles from a referral center would rather have telecolposcopy locally than to drive to the referral center. ${ }^{23}$

Table 5. Colposcopy CPT $\operatorname{codes}^{25-27}$

\begin{tabular}{|c|c|c|c|c|}
\hline CPT Code & Description of Examination & $\begin{array}{l}\text { Medicare Prof Fee When } \\
\text { Performed in Facility }\end{array}$ & $\begin{array}{l}\text { Medicare Prof Fee When } \\
\text { Performed in Clinic }\end{array}$ & $\begin{array}{l}\text { Medicaid WI } \\
\text { Physician Fee }\end{array}$ \\
\hline 56820 & Colposcopy of the vulva & 81.73 & 106.36 & 一 $^{*}$ \\
\hline 56821 & with biopsy(s) & 112.93 & 143.45 & - $^{*}$ \\
\hline 57420 & $\begin{array}{l}\text { Colposcopy of the entire vagina, with } \\
\text { cervix if present }\end{array}$ & 86.86 & 111.48 & - $^{*}$ \\
\hline 57421 & with biopsy(s) & 120.61 & 152.17 & $一^{*}$ \\
\hline 57452 & $\begin{array}{l}\text { Colposcopy of the cervix including upper } \\
\text { vagina }\end{array}$ & 81.73 & 108.44 & - $^{*}$ \\
\hline 57454 & $\begin{array}{l}\text { With biopsy(s) of the cervix and } \\
\text { endocervical curettage }\end{array}$ & 126.85 & 153.21 & 90.47 \\
\hline 57455 & With biopsy(s) of the cervix & 109.65 & 140.17 & $一^{*}$ \\
\hline 57456 & With endocervical curettage & 102.68 & 132.51 & - $^{*}$ \\
\hline 57460 & $\begin{array}{l}\text { With loop electrode biopsy(s) of the } \\
\text { cervix }\end{array}$ & 158.96 & 325.81 & 294.88 \\
\hline 57461 & $\begin{array}{l}\text { With loop electrode conization of the } \\
\text { cervix }\end{array}$ & 187.96 & 357.57 & - $^{*}$ \\
\hline 57500 & $\begin{array}{l}\text { Biopsy, single or multiple, or local } \\
\text { excision of lesion, with or without } \\
\text { fulguration (separate procedure) }\end{array}$ & 56.4 & 132.36 & 56.20 \\
\hline 57505 & Endocervical curettage & 85.24 & 98.08 & 59.80 \\
\hline 57511 & Cryocautery, initial or repeat & 125.91 & 141.87 & 67.90 \\
\hline 57522 & Loop electrode excision & 230.93 & 289.21 & 298.00 \\
\hline 58100 & Endometrial sampling (biopsy) & 84.68 & 105.84 & 54.69 \\
\hline 99170 & Colposcopy of perineum & 85.96 & 127.58 & 132.52 \\
\hline
\end{tabular}

* No fee listed in schedule; fee based on individual consideration, medical consultant.

Note: fees are for Wisconsin. A geographic adjustment factor (GAF) between 0.84 and 1.30 is multiplied by a national figure to calculate state value. 


\section{ICD-9 Codes and CPT-4 Codes and Charges}

Please see Tables 4 and 5 for colposcopy-related outpatient codes and charges.

\section{Resources}

Colposcopy resources include books (Table 2) and CD ROMs (Table 3). The American Academy of Family Physicians (AAFP) and ASCCP regularly hold colposcopy courses, which can be found on their respective web sites: www.aafp.org and www. asccp.org. The ASCCP offers a Colposcopy Mentorship Program, which requires a minimum of 25 supervised colposcopies, with at least three highgrade findings, and successful completion of a written and slide examination. Documentation of successful program completion is awarded, but there is no certification for colposcopy.

\section{Conclusions}

Colposcopy is an important component of cervical cancer screening. An evidence-based approach to colposcopy requires familiarity with 2001 ASCCP Consensus Guidelines. By following these guidelines and reviewing new evidence as it develops, family physicians can play a valuable role in cervical cancer screening with Papanicolaou tests and colposcopies, an approach that has reduced cervical cancer rates by $75 \%$ in the United States.

\section{References}

1. Koliopoulos G, Martin-Hirsch P, Paraskevaidis E, Arbyn M. HPV testing versus cervical cytology for screening for cancer of the uterine cervix. Cochrane Gynaecological Cancer Group. Cochrane Database of Systematic Reviews, 2004.

2. US Preventive Services Task Force. Screening for cervical cancer: recommendations and rationale. American Family Physician 2003;67:1759-66.

3. Spitzer M, Apgar B, Brotzman G, Krumhoz BA. Residency training in colposcopy: a survey of program directors in obstetrics and gynecology and family practice. Am J Obstet Gynecol 2001;185:507-13.

4. Wright TC Jr, Cox JT, Massad LS, Twiggs LB, Wilkinson EJ. Consensus guidelines for the management of women with cervical cytological abnormalities. JAMA 2001;287:2120-9.

5. Solomon D, Davey D, Kurman R, et al. Forum Group Members. Bethesda 2001 Workshop. The 2001 Bethesda System: terminology for reporting results of cervical cytology. JAMA 2002;287:2114-9.
6. Wright T, Schiffman M, Solomon D, et al. Interim guidance for the use of human papillomavirus DNA testing as an adjunct to cervical cytology for screening. Obstet Gynecol 2004;103:304-9.

7. Kim JJ, Wright TC, Goldie SJ. Cost-effectiveness of alternative triage strategies for atypical squamous cells of undetermined significance. JAMA 2002;287: 2382-90.

8. The cervix: colposcopy: high grade cervical intraepithelial neoplasia: cytology, histology, and colposcopy. American Society for Colposcopy and Cervical Pathology. http://www.asccp.org/edu/practice/cervix/ colposcopy/highgrade.shtml. Site last visited March 28, 2005.

9. Wright TC Jr, Cox JT, Massad LS, Carlson J, Twiggs LB, Wilkinson EJ. 2001 Consensus guidelines for the management of women with cervical intraepithelial neoplasia. Am J Obstet Gynecol 2003; 189:295-304.

10. The ASCUS-LSIL Study (ALTS) Group. A randomized trial on the management of low-grade intraepithelial lesion cytology interpretations. Am J Obstet Gynecol 2003;188:1393-400.

11. Levine L, Lucci JA, Dinh TV. Atypical glandular cells: new Bethesda terminology and management guidelines. Obstet Gynecol Survey 2003;58: $399-406$.

12. Britton H, Hansen K. Sexual abuse. Clin Obstet Gynecol 1997;40:226-40.

13. Hobbs C, Wynne J. Use of colposcope in examination for sexual abuse. Arch Disease Childhood 1996; 75:539-42.

14. The cervix: colposcopy: colposcopic appearance of benign lesions. American Society for Colposcopy and Cervical Pathology. http://www.asccp.org/edu/ practice/cervix/colposcopy/benign.shtml. Site last visited March 28, 2005.

15. Dresang LT. Cervical cancer with a normal Pap. WMJ 2003;102:4.

16. Boardman LA, Meinz H, Steinhoff MM, Heber WW, Blume J. A randomized trial of the sleeved cytobrush and the endocervical curette. Obstet Gynecol 2003;101:426-30.

17. Palle C, Bangsboll S, Andreasson B. Cervical intraepithelial neoplasia in pregnancy. Acta Obstet Gynecol Scand 2000;79:306-10.

18. Nuovo J, Melnikow J, Howell L. New tests for cervical cancer screening. Am Fam Physician 2001; 64:780-6.

19. Tseng DS, Cox E, Plane MB, Hia KM. Efficacy of patient letter reminders on cervical cancer screening. A meta-analysis. J Gen Intern Med 2001;16:563-8.

20. Ferris DG, Litaker MS, Macfee MS, Miller JA. Remote diagnosis of cervical neoplasia: 2 types of telecolposcopy compared with cervicography. J Fam Pract 2003;52:298-304. 
21. Susman J. Telemedicine marches on: the efficacy of remote telecolposcopy (Editorial). J Fam Pract 2003; $52: 264$.

22. Bishai DM, Ferris DG, Litaker MS. What is the least costly strategy to evaluate cervical abnormalities in rural women? Comparing telemedicine, local practitioners, and expert physicians. Med Decis Making 2003;23:463-70.

23. Harper DM, Moncur MM, Harper WH, Burke GC, Rasmussen CA, Mumford MC. The technical performance and clinical feasibility of telecolposcopy. J Fam Pract 2000;49:623-7.
24. Puckett CD. The educational annotation of ICD-9$\mathrm{CM}$, 5th Ed. Reno (NV): Channel Publishing Ltd.; 2003.

25. American Medical Association. Current Procedural Terminology: 2004. Chicago (IL): AMA Press; 2003.

26. Medicare Fees based on Medicare Part B Physician Fee Schedule. http://www.wpsic.com/medicare/ provider/pricing_fees.shtml. Site last visited March 28, 2005.

27. Medicaid Fees based on WI Medicaid Fee Schedule. http://dhfs.wisconsin.gov/medicaid4/maxfees/maxfee. htm\#medicaid. Site last visited March 28, 2005. 